\title{
PENGEMBANGAN TRAINING KIT PADA MATA PELAJARAN MENGOPERASIKAN SISTEM KENDALI ELEKTRONIK
}

\author{
Krismadinata'), Anwar'), Junaidi Akbar ${ }^{3)}$ \\ Teknik Elektro, Fakultas Teknik, Universitas Negeri Padang \\ Email: krisma@ft.unp.ac.id, sananwar52@gmail.com, junakbar31@gmail.com
}

\begin{abstract}
ABSTRAK
Rendahnya ketertarikan siswa pada mata pelajaran mengoperasikan sistem kendali elektronik menyebabkan rendahnya capaian hasil pembelajaran. Artikel ini membahas proses perancangan dan pembuatan produk training kit kendali elektronik dan mengetahui tingkat kelayakannya dengan mengukur tingkat validitas, kepraktisan, efektivitas serta mengetahui hasil belajar peserta didik ketika menggunakan training kit kendali elektronik yang dikembangkan. Metode penelitian yang digunakan adalah penelitian dan pengembangan Borg \& Gall. Tahapan yang dilakukan yakni dengan identifikasi potensi dan masalah, pengumpulan informasi, desain produk, validasi desain, revisi desain, ujicoba produk, revisi produk, ujicoba pemakaian, revisi produk, produk final. Hasil validitas rata-rata persentase yang diperoleh adalah $91 \%$ dikategorikan sangat layak ditinjau dari komponen isi dan tujuan, instruksional dan teknis. Kepraktisan rata-rata persentase yang diperoleh adalah 90,3\% dengan kategori sangat praktis di tinjau dari kemudahan penggunaan, waktu yang diperlukan dalam pelaksanaan, mudah di interprestasikan dan memiliki ekivalensi. Kefektivitas rata-rata persentase yang diperoleh adalah $91,87 \%$, dikategorikan sangat efektif di tinjau dari ketuntasan siswa terhadap materi yang diajarkan menggunakan media training kit yang dikembangkan. Berdasarkan hasil analisis data tentang validasi, kepraktisan, dan efektifitas training kit kendali elektronik yang dikembangkan dapat disimpulkan bahwa sejalan dengan bidang pendidikan yakni menghasilkan produk pembelajaran yang efektif digunakan di sekolah-sekolah.
\end{abstract}

Kata kunci: training kit kendali elektronik, valid, praktis, efektif

\begin{abstract}
The low interest of students in the subject of operating an electronic control system results in low learning outcomes. This article discusses the process of designing and manufacturing an electronic control training kit product and knowing its feasibility level by measuring the level of validity, practicality, effectiveness and knowing the learning outcomes of students when using the developed electronic control training kit. The research method used was the research and development of Borg \& Gall. The steps taken are identification of potentials and problems, gathering information, product design, design validation, design revision, product testing, product revision, trial use, product revision, final product. The result of the average percentage validity obtained is $91 \%$ categorized as very feasible in terms of content and objectives, instructional and technical components. Practicality the average percentage obtained is $90.3 \%$ with a very practical category in terms of ease of use, time required in implementation, easy to interpret and has equivalence. The effectiveness of the average percentage obtained was $91.87 \%$, categorized as very effective in terms of students' completeness on the material being taught using the developed training kit media. Based on the results of data analysis about the validation, practicality, and effectiveness of the developed electronic control training kit, it can be concluded that it is in line with the education sector, namely producing learning products that are effectively used in schools.
\end{abstract}

Keywords : electronic control kit training, valid, practical, effective 


\section{PENDAHULUAN}

Seiring dengan era globalisasi, teknologi informasi dan komunikasi telah berkembang sangat pesat, sehingga interaksi dan penyampaian informasi akan berlangsung dengan cepat. Pengaruh globalisasi ini dapat berdampak positif dan negatif pada suatu negara. Orang-orang dari berbagai belahan dunia dapat saling bertukar informasi, ilmu pengetahuan dan teknologi [1]. Sebagaimana menurut [2], [3] Pendidikan adalah suatu hal yang sangat penting dalam suatu negara, kemajuan suatu negara akan tercermin salah satunya dari kualitas pendidikan yang ada pada suatu negara tersebut. Berkualitas atau tidaknya pendidikan itu tergantung pada sistem pendidikan yang diterapkan. Apabila sistem pendidikan yang diterapkan sudah baik maka pendidikan yang dihasilkanpun juga akan semakin berkualitas, namun jika sebaliknya sistem pendidikan yang diterapkan belum baik dan tidak dirumuskan secara matang maka kualitas pendidikan juga akan menurun.

Sekolah sebagai lembaga pendidikan formal mempunyai peranan penting dalam proses adaptasi siswa menjadi generasi yang tidak tertinggal dalam menghadapi perkembangan teknologi. Menurut [4] Sekolah Menengah Kejuruan (SMK) merupakan salah satu bentuk lembaga pendidikan formal yang dituntut mampu mengikuti perkembangan teknologi sehingga menghasilkan lulusan yang kompeten secara kognitif, psikomotorik, dan afektif. Pengenalan teknologi baru harus dilakukan dalam proses kegiatan belajar mengajar di SMK agar peserta didik mampu menjadi siswa yang siap dalam menghadapi tantangan dunia diera teknologi. Kualitas proses belajar mengajar akan berpengaruh terhadap hasil belajar peserta didik. Salah satu faktor yang dapat mendukung kualitas hasil belajar siswa adalah ketersediaan media pembelajaran [5].

Menurut [6], [7] dalam suatu proses belajar mengajar, ada dua unsur yang sangat penting, yaitu metode mengajar dan media pembelajaran, Kedua aspek ini saling berkaitan, pemilihan metode mengajar tertentu akan mempengaruhi media yang digunakan.

Sebagaimana menurut [8], [9], [10] banyak alat atau media pembelajaran diciptakan untuk belajar mandiri, tetapi untuk menemukan pilihan atau solusi yang ada sangat bagus untuk proses belajar menjadi efektif, menarik dan menyenangkan adalah masalah yang perlu dicari solusinya. Alat bantu atau media untuk pembelajaran mandiri di era ini. Kemajuan teknologi sangat dibutuhkan dalam proses pembelajaran, namun tidak dipungkiri keberadaan media juga memberi pengaruh besar dalam pendidikan [11].

Ketersediaan jumlah media pembelajaran merupakan hal yang cukup penting untuk menunjang proses belajar mengajar terutama di SMK yang mengharuskan lulusannya memiliki keterampilan sesuai jurusan yang diambil. Terbatasnya jumlah atau kelengkapan media pembelajaran yang menunjang kegiatan praktikum siswa pada tiap-tiap mata pelajaran merupakan salah satu masalah yang cukup sering dihadapi oleh SMK, salah satunya di SMK Negeri 2 Lubuk Basung.

Mata pelajaran Mengoperasikan Sistem Kendali Elektronik (MSKE) merupakan salah satu mata pelajaran produktif yang diberikan kepada siswa kelas XI program studi Teknik Instalasi Tenaga Listrik (TITL) di SMK N 2 Lubuk Basung. Pada mata pelajaran MSKE siswa mempelajari dan menyiapkan dirinya untuk mampu mengenal serta menguasai konsep sistem kendali elektronik yaitu komponen aktif (SCR, Transistor, TRIAC, dan IC). Media pembelajaran merupakan sarana yang dapat mendukung tercapainya tujuan pembelajaran.

Hasil observasi pelaksanaan kegiatan belajar serta penggunaan alat penunjang kegiatan praktek di SMKN 2 Lubuk Basung menunjukkan bahwa penggunaan alat praktek sebelumnya dalam belajar belum optimal membantu tercapainya tujuan pelajaran. Kelemahan alat penunjang kegiatan praktek yang digunakan selama ini diantaranya tidak mengarahkan siswa pada proses pemikiran kritis, kreatif dan mandiri, media yang digunakan masih berupa software aplikasi untuk simulasi rangkaian pada saat praktikum serta metode ceramah, banyak siswa yang kurang menguasai materi pelajaran karena tidak dapat mengaplikasikan langsung pakai alat atau komponen yang lebih nyata seperti yang ada pada training kit, hal ini menyebabkan hasil belajar siswa banyak berada di bawah Kriteria Ketuntasan Minimum (KKM).

Bila kondisi pembelajaran ini dibiarkan akan berdampak negatif terhadap hasil belajar. Untuk mencapai tujuan pembelajaran MSKE, idealnya diperlukan training kit yang bisa mensimulasikan sistem kendali elektronik. Hal ini disebabkan karena mata pelajaran MSKE bersifat konkrit, memerlukan contoh dan implementasi langsung. Media juga diharapkan bisa menjawab dan membuktikan materi yang dipelajari secara teoritis untuk diaplikasikan.

Media training kit kendali elektronik dikembangkan agar mampu memberi solusi terhadap keterbatasan media training kit kendali elektronik yang digunakan dalam proses pembelajaran. Tujuannya adalah agar siswa mudah memahami pelajaran dengan menggunakan training kit serta dapat menumbuhkan kemampuan intelektual, psikomotor, dan kualitas pembelajaran siswa. 
Berdasarkan keterbatasan media training kit yang ada tersebut menjadi latar belakang media training kit sistem kendali elektronik dikembangkan.

Media training kit kendali elektronik dirancang menarik agar siswa lebih termotivasi dalam mengikuti proses pembelajaran. Untuk menyampaikan pesan dari guru kepada siswa, biasanya guru menggunakan alat bantu mengajar (reaching aids) berupa gambar, model, atau alat bantu lain yang dapat memberikan pengalaman konkrit, motivasi belajar, serta mempertinggi daya serap atau yang kita kenal dengan alat bantu visual [12], [13].

Pengembangan training kit dalam rangka penyempurnaan alat penunjang kegiatan praktek lama diharapkan menjadi solusi praktis menjawab permasalahan di atas. kelangkaan materi ajar (perangkat pembelajaran) dalam poses pembelajaran yang sesuai dengan kebutuhan belajar dapat diatasi dengan melakukan penelitian pengembangan yang dilakukan [14], [15].

Seiring dengan hal itu diperlukan adanya training kit sistem kendali elektronik yang dapat membantu berjalannya proses belajar dengan baik sehingga tercipta kondisi belajar yang berpusat pada siswa. Menurut [16], [17] media pembelajaran membantu mengkonkritkan konsep atau gagasan dan membantu memotivasi peserta belajar aktif. Bagi siswa, media dapat menjadi jembatan untuk berpikir kritis dan berbuat.

Media yang dikembangkan didukung dengan jobsheet pembelajaran sebagai sumber belajar yang memungkinkan siswa belajar mandiri pada pelaksanaan pembelajaran. Kelebihan pengembangan training kit ini adalah adanya komponen regulator untuk mengatur tegangan output sesuai dengan yang kita inginkan, output berupa loudspeaker, lampu dan LED. Training kit kendali elektronik mempunyai potensi untuk menjadi media pembelajaran karena memiliki beberapa kelebihan diantaranya dapat dijadikan sebagai alat peraga atau mempraktikkan rangkaian-rangkaian sistem kendali elektronik tanpa membutuhkan waktu yang lama karena training kit ini menggunakan kabel jumper, sehingga menjadikan training kit kendali elektronik sebagai media yang menarik dan mudah dipahami oleh siswa.

Berdasarkan uraian diatas, maka perlu dilakukan penelitian tentang pengembangan training kit kendali elektronik yang valid, praktis, dan efektif pada mata pelajaran Mengoperasikan Sistem Kendali Elektronik di SMKN 2 Lubuk Basung.

\section{METODE}

Berisi bagaimana data dikumpulkan, sumber data dan cara analisis data. Untuk penelitian jenis eksperimental, bisa menambahkan bab Penelitian Terkait yang dipaparkan sebelum bab Metode. Pada bab Penelitian Terkait, disampaikan penelitian-penelitian yang sudah pernah dilakukan terkait topik yang diteliti, sehingga bisa menjadi dasar kebaharuan dari penelitian yang dilakukan. Jenis penelitian yang digunakan dalam penelitian ini adalah penelitian dan pengembangan Research \& Development (R\&D). Penelitian ini digunakan untuk menghasilkan training kit kendali elektronik yang valid, praktis, dan efektif. Penelitian pengembangan adalah metode penelitian yang digunakan untuk menghasilkan produk tertentu, dan menguji keefektifan produk tersebut [18], [19]. Model penelitian pengembangan yang digunakan mengacu pada Borg \& Gall karena model penelitian ini cocok untuk mengembangkan perangkat pembelajaran. Langkah penelitian pengembangan yang akan dilakukan dapat dilihat seperti pada gambar 1 .

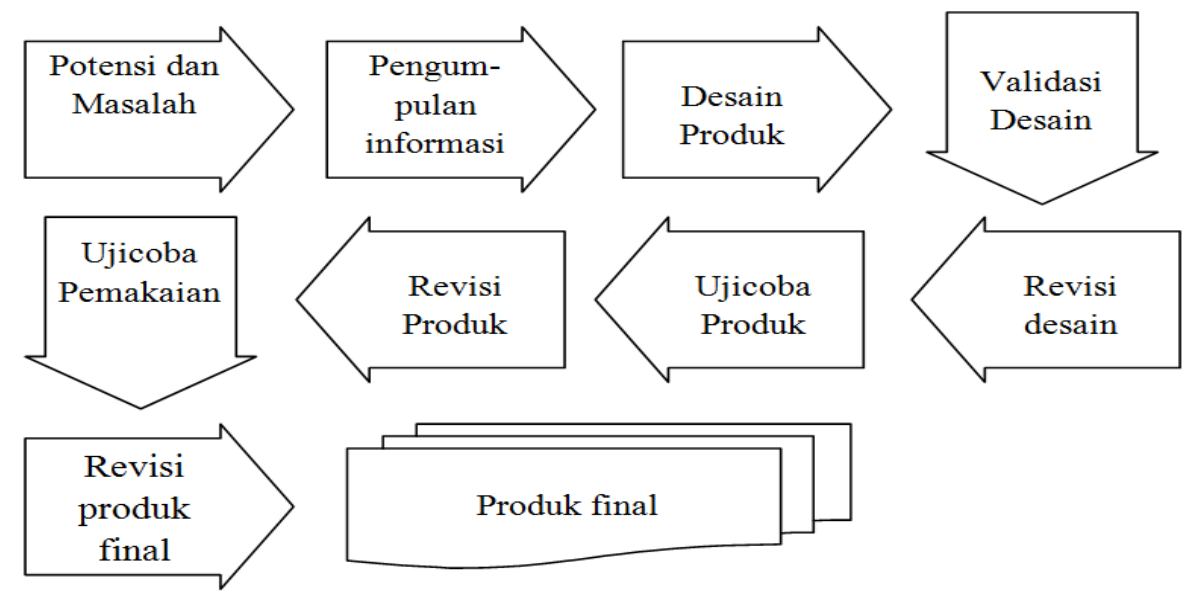

Gambar 1. Langkah R\&D 
Potensi dan masalah merupakan media pembelajaran yang menjadi pedoman peserta didik dalam melakukan kegiatan belajar, dalam kegiatan belajar inilah nantinya peserta didik akan mengembangkan keterampilan dan keahliannya. Untuk mengembangkan keterampilan dan keahlian peserta didik, maka diperlukan pendayagunaan media pembelajaran untuk menunjang proses belajar. Media merupakan model pembelajaran yang paling baik digunakan dalam mengembangkan kemampuan atau keterampilan peserta didik karena memberikan pengalaman langsung. Hal inilah yang menjadi masalah dalam penelitian ini. Ketidaktersediaan media pembelajaran yang sesuai karakteristik mata pelajaran tentu menghambat tercapainya tujuan pembelajaran.

Kegiatan pada tahap pengumpulan informasi meliputi pengamatan langsung bertujuan untuk melihat dan mengamati langsung kegiatan peserta didik selama proses pelaksanaan proses pembelajaran. Sehingga diperoleh informasi hal-hal yang menjadi kendala peserta didik selama pelaksanaan praktikum. Melakukan wawancara dengan guru mata pelajaran. Tujuan dari wawancara ini adalah untuk mengetahui kendala-kendala yang dihadapi guru dalam pelaksanaan pembelajaran. Mengidentifikasi dilakukan untuk mengetahui tujuan yang akan dicapai dari setiap materi yang disampaikan guru mata pelajaran. Identifikasi jobsheet dilakukan untuk mengetahui topik-topik praktikum yang akan dilaksanakan.

Kegiatan Desain produk training kit meliputi rancangan produk, komponen yang dibutuhkan, alat dan bahan serta membuat keunggulan training kit.

Validasi Desain Trainer merupakan proses validasi desain dilakukan oleh beberapa orang pakar atau ahli yang berpengalaman dalam menilai desain media pembelajaran. Rancangan desain trainer yang akan divalidasi disiapkan dalam bentuk lembaran validasi.

Revisi desain merupakan proses revisi desain training kit dilakukan jika secara rasional rancangan desain yang diajukan belum dinilai valid oleh validator. Namun jika rancangan desain trainer sudah valid maka dapat dilakukan proses selanjutnya yaitu pembuatan trainer.

Pembuatan produk merupakan proses pembuatan training kit dapat dilaksanakan setelah rancangan desain trainer sudah divalidasi dan disahkan oleh validator. Training kit yang dihasilkan harus sesuai dengan rancangan desain yang telah divalidasi. Selanjutnya disiapkan lembaran validasi untuk menguji kualitas dari trainer yang dikembangkan ini.

Validasi produk merupakan proses pembuatan produk selesai, dilanjutkan dengan proses validasi oleh validator. produk ini diuji coba dihadapan validator, kemudian validator menilai dan memberikan rekomendasi produk sudah valid atau tidak. Jika trainer ini dinyatakan sudah valid maka dilanjutkan ke proses berikutnya yaitu uji kepraktisan dan uji coba terbatas oleh pengguna. Namun jika belum valid maka perlu dilakukan revisi kembali sampai dinyatakan valid oleh validator.

Revisi dilakukan untuk menyempurnakan produk sesuai hasil validasi dan saran-saran yang diberikan oleh validator. Setelah dilakukan proses revisi, hasilnya kembali akan dikonfirmasikan kepada validator untuk mendapatkan persetujuan.

Uji Coba sebagai proses pelaksanaannya adalah dengan menerapkan peserta didik sebagai pengguna produk yang akan dilaksanakan. Jika hasil sudah sesuai dengan yang diharapkan yakni praktisdan efektif, berarti produk sudah dapat dijadikan produk akhir. Jika ada kekurangan atau kelemahan maka harus diperbaiki dahulu dan dilakukan uji coba kembali sebelum dijadikan produk akhir.

Produk Akhir merupakan proses dari perancangan hingga uji coba training kit, diperoleh produk yang telah memenuhi kriteria, dinyatakan valid, praktis dan efektif dalam penggunaannya.

Penelitian ini dilakukan di SMKN 2 Lubuk Basung. Subjek uji coba penelitian ini adalah siswa kelas XI Teknik Instalasi Tenaga Listrik SMKN 2 Lubuk Basung. Siswa subjek uji coba penelitian berjumlah 32 orang.

Menurut [20] Teknik analisis validitas media training kit dilakukan sebagai penilaian valid produk yang dikembangkan. Berdasarkan hasil nilai validitas yang diperoleh, kemudian dapat dikategorikan sesuai dengan tingkat kevalidan pada tabel 1 .

Tabel 1. Kategori validasi produk

\begin{tabular}{ccc}
\hline No & Tingkat Pencapaian (\%) & Kategori \\
\hline 1 & $81-100$ & Sangat Valid \\
2 & $61-80$ & Valid \\
3 & $41-60$ & Cukup Valid \\
4 & $21-40$ & Kurang Valid \\
5 & $0-20$ & Tidak Valid \\
\hline
\end{tabular}


Pemberian nilai validitas dengan cara,

Nilai Valid $=\frac{\text { Iumlah skor yang diperoleh }}{\text { Jumlah skor maksimum }} \times 100 \%$

Teknik analisis praktikalitas dilakukan setelah semua angket diisi. Analisis praktikalitas ini digunakan untuk analisis data hasil pengamatan penggunaan media training kit, angket respon dosen mata kuliah dan respon mahasiswa. Berdasarkan hasil nilai praktikalitas yang diperoleh, kemudian dikategorikan sesuai dengan tingkat kepraktisan pada tabel 2.

Tabel 2. Kategori kepraktisan produk

\begin{tabular}{ccc}
\hline No & Tingkat Pencapaian $(\%)$ & Kategori \\
\hline 1 & $81-100$ & Sangat Praktis \\
2 & $61-80$ & Praktis \\
3 & $41-60$ & Cukup Praktis \\
4 & $21-40$ & Kurang Praktis \\
5 & $0-20$ & Tidak Praktis \\
\hline
\end{tabular}

Pemberian nilai kepraktisan dengan cara,

Nilai Praktis $=\frac{\text { Iumlah skor yang dipperoleh }}{\text { Iumlah skor maksimum }} \times 100 \%$

Teknik Analisis efektivitas produk yang dikembangkan (media pembelajaran training kit) dilihat dari penguasaan siswa terhadap materi yang diajarkan menggunakan media training kit yang dikembangkan. Uji efektivitas dilakukan bersamaan dengan uji coba produk dan uji coba pemakaian. Efektivitas produk dilihat dari jumlah siswa yang memperoleh nilai $\geq 79$. Kategori efektifitas dapat dilihat pada tabel 3 .

Tabel 3. Kategori efektivitas produk

\begin{tabular}{lll}
\hline No & Tingkat Pencapaian (\%) & Kategori \\
\hline 1 & $81-100$ & Sangat efektif \\
2 & $61-80$ & Efektif \\
3 & $41-60$ & Cukup Efektif \\
4 & $21-40$ & Kurang Efektif \\
5 & $0-20$ & Tidak Efektif \\
\hline
\end{tabular}

Perolehan nilai siswa dihitung menggunakan rumus berikut:

$$
\mathrm{K}=\frac{x}{x m} \times 100 \%
$$

Keterangan:

$\begin{array}{ll}\mathrm{K} & =\text { Nilai } \\ \mathrm{X} & =\text { Skor yang diperoleh } \\ \mathrm{Xm} & =\text { Skor maksimum }\end{array}$

\section{HASIL DAN PEMBAHASAN}

Potensi dan masalah yang didapat yaitu berupa belum optimalnya penggunaan media pembelajaran, kurangnya minat siswa dalam mata pelajaran mengoperasikan sistem kendali elektronik, Ketika pembelajaran sedang berlangsung siswa hanya diberikan materi dan tugas untuk melakukan praktikum tanpa melihat produk akhir yang digambarkan secara penerapannya dalam sehari-hari maupun dalam dunia industri. kemudian Langkah pada tahap ini dilakukan dengan cara pengamatan kegiatan belajar yang dilakukan di sekolah, melakukan wawancara dengan guru mata pelajaran, mengidentifikasi kebutuhan media pembelajaran, dan mengidentifikasi kelemahan media yang terdapat di sekolah. Validasi Desain, merupakan suatu proses kegiatan untuk menilai kesesuaian rancangan training kit dengan materi pada mata pelajaran mengoperasikan sistem kendali elektronik. 
Tahap pertama membuat desain produk, bertujuan untuk mendapatkan hasil produk yang lebih baik sebelum dibuat dalam bentuk nyata, desain diperoleh dari hasil evaluasi kelemahan - kelemahan dan permasalahan dari media pembelajaran sebelumnya. Melakukan rancangan training kit mengacu pada kebutuhan dan solusi permasalahan, rancangan dapat dilihat pada gambar 2 .

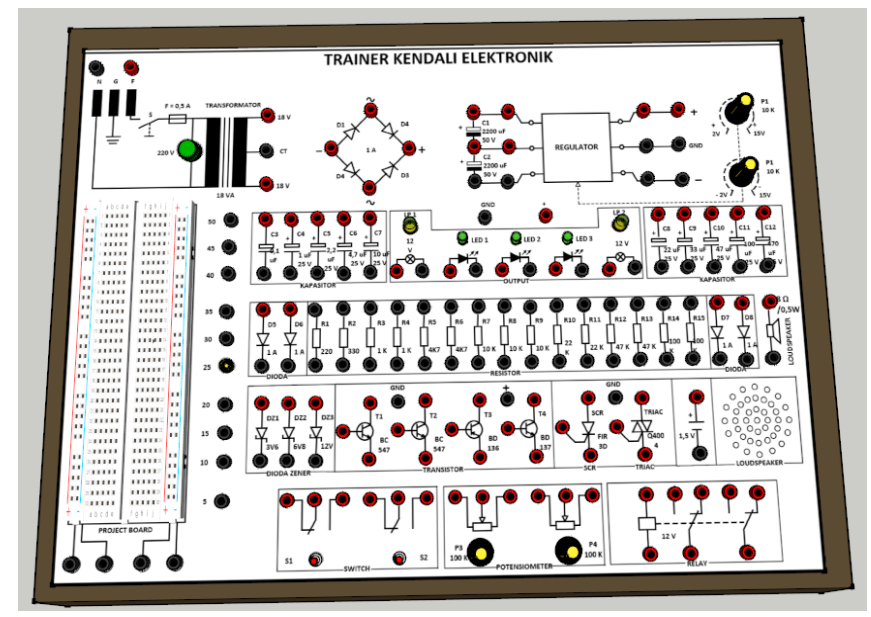

Gambar 2. Desain training kit kendali elektronik tampak atas 3.

Ukuran training kit kendali elektronik tampak dari samping sebelah kiri bisa dilihat pada gambar

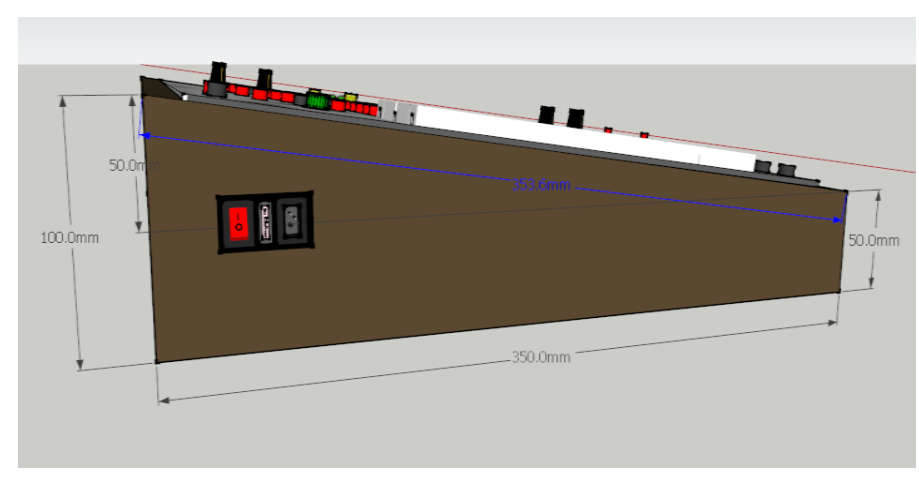

Gambar 3. Training kit tampak dari samping kiri

Komponen penyusun Training kit dapat dilihat pada tabel 4 .

Tabel 4. Penyusunan Komponen Training kit

\begin{tabular}{cccc}
\hline No & Nama Komponen & Jumlah & Satuan \\
\hline 1 & Lampu Indikator & 1 & Buah \\
2 & Trafo CT & 1 & Buah \\
3 & Saklar & 1 & Buah \\
4 & Fuse & 1 & Buah \\
5 & SCR FIR3D 41 & 1 & Buah \\
6 & Transistor & 4 & Buah \\
7 & TRIAC Q4004 & 1 & Buah \\
8 & IC NE555 & 1 & Buah \\
10 & LED & 3 & Buah \\
11 & Lampu pijar & 2 & Buah \\
12 & Resistor & 15 & Buah \\
13 & Tombol switch & 2 & Buah \\
14 & Breadboard & 1 & Buah \\
15 & Relay 12 V & 1 & Buah \\
16 & Papan dudukan training kit & 1 & Unit \\
\hline
\end{tabular}


Setelah melakukan tahapan desain produk maka langkah selanjutnya yaitu melakukan perancangan produk. Pada tahapan pengembangan media training kit sistem kendali elektronik dan mengembangkan Produk. Hasil pengembangan media pembelajaran training kit dapat dilihat pada gambar 4.

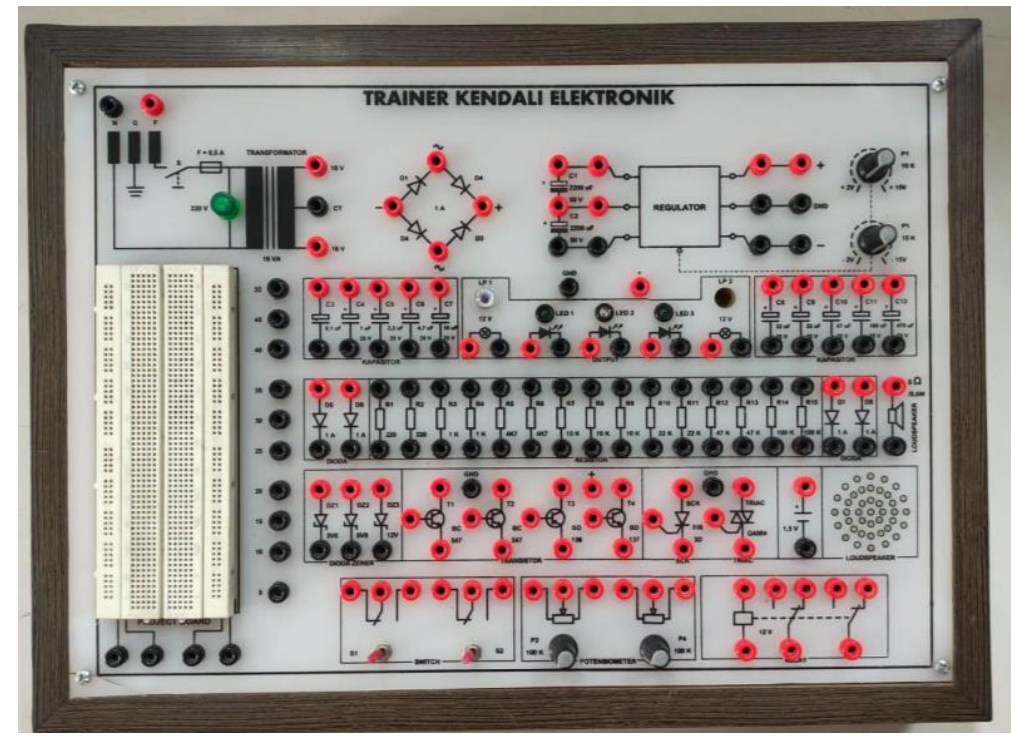

Gambar 4. Hasil Produk Training Kit Sistem Kendali Elektronik

Tahap Kedua, menghitung hasil validasi produk. Setelah training kit kendali elektronik didesain dan dibuat, training kit divalidasi sebelum digunakan dalam pembelajaran. Validasi dilakukan oleh validator yang mempunyai kompetensi dalam bidang media pembelajaran dan materi pembelajaran MSKE. Adapun hasil validasi training kit kendali elektronik oleh masing-masing validator dapat dilihat pada gambar 5.

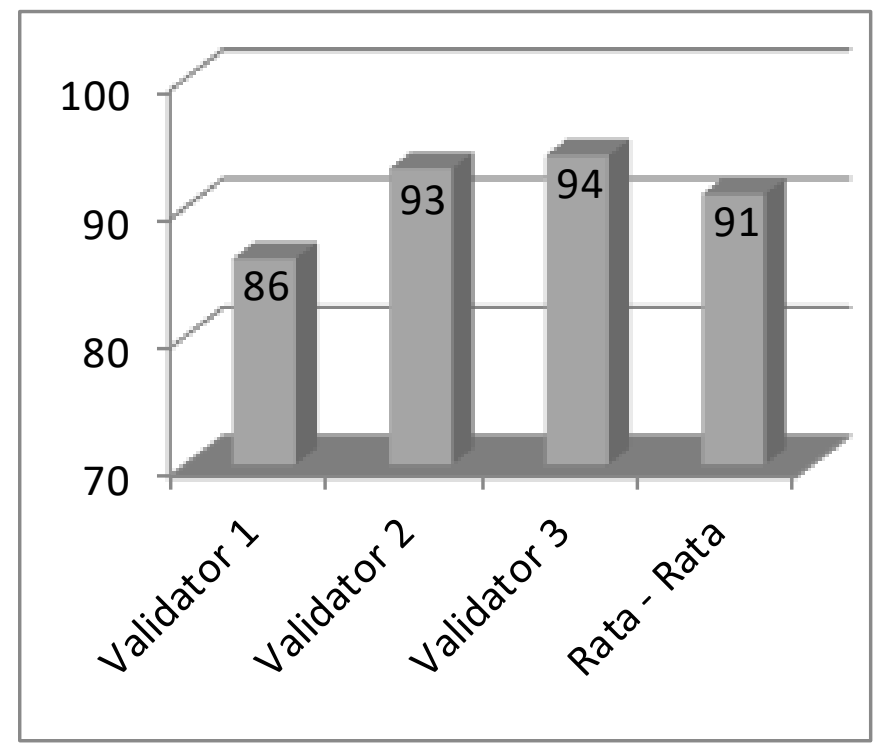

Gambar 5. Hasil Validasi Training Kit Kendali Elektronik

Berdasarkan pada gambar 5 dapat dilihat bahwa rata-rata persentase yang diperoleh adalah 91\%, sehingga media training kit kendali elektronik tersebut dikategorikan sangat valid.

Tahap ketiga, setelah training kit kendali elektronik dikatakan valid, maka training kit kendali elektronik di uji kepraktisannya oleh guru mata pelajaran MSKE dan siswa kelas XI TITL dengan mengisi angket. Adapun hasil praktikalitas training kit kendali elektronik dapat dilihat pada gambar 6 . 


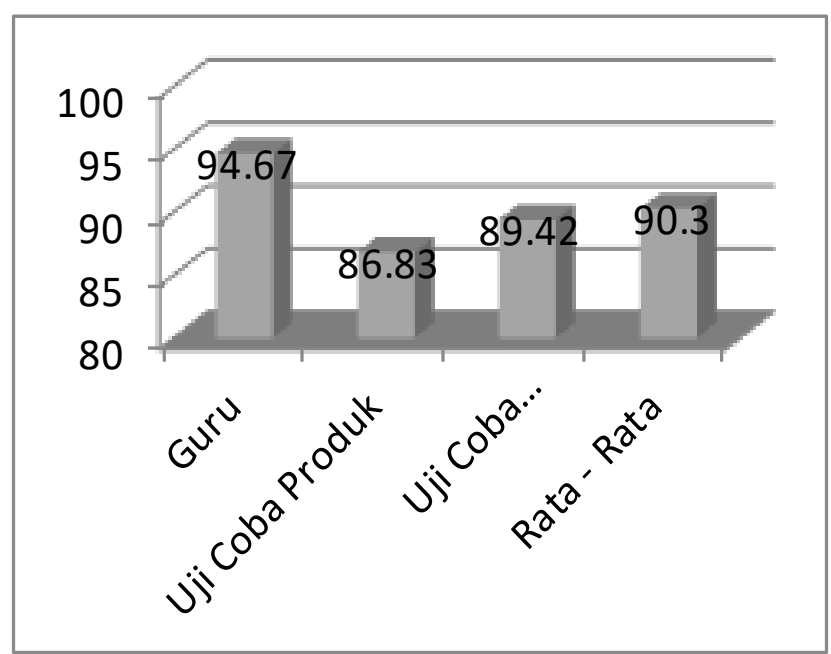

Gambar 6. Hasil Praktikalitas Training Kit Kendali Elektronik

Berdasarkan pada gambar 6 diatas dapat dilihat bahwa rata-rata persentase yang diperoleh adalah 90,3\%, sehingga media training kit kendali elektronik tersebut dikategorikan sangat praktis.

Tahap keempat, menghitung hasil efektifitas produk. Setelah training kit kendali elektronik dikatakan valid dan praktis, maka training kit kendali elektronik di uji keefektifitisannya pada siswa kelas XI TITL dengan uji keterampilan. Adapun hasil efektifitas training kit kendali elektronik dapat dilihat pada gambar 7 .

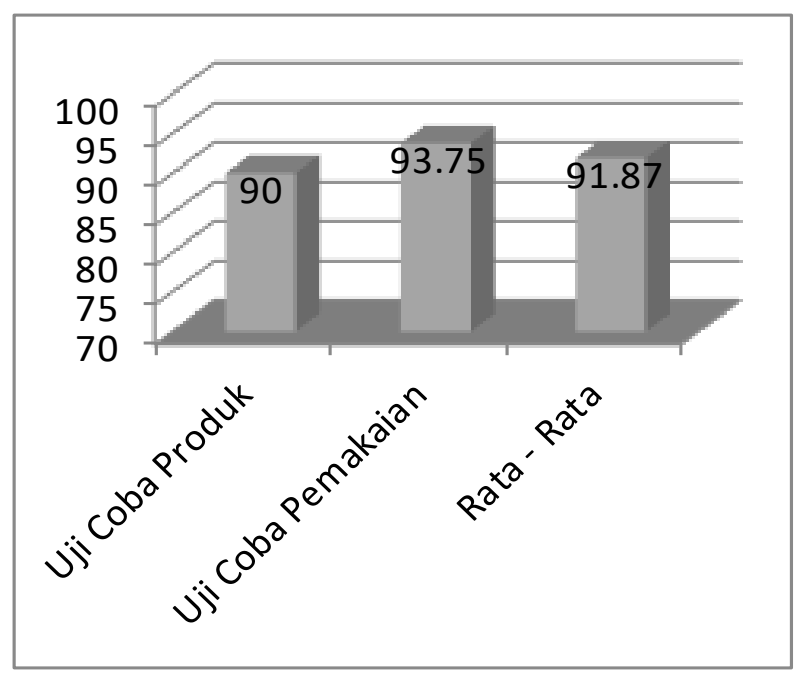

Gambar 7. Hasil Efektifitas Training Kit Kendali Elektronik

Berdasarkan pada gambar 7 diatas dapat dilihat bahwa rata-rata persentase yang diperoleh adalah $91,87 \%$, sehingga media training kit kendali elektronik tersebut dikategorikan sangat efektif.

\section{SIMPULAN DAN SARAN}

Sejalan dengan tujuan penelitian pengembangan dalam bidang pendidikan yakni menghasilkan produk-produk pendidikan yang efektif digunakan di sekolah-sekolah, maka penelitian ini telah menghasilkan produk pendidikan berupa training kit kendali elektronik pada mata pelajaran Mengoperasikan Sistem Kendali Elektronik yang valid, praktis dan efektif yang dapat digunakan untuk pembelajaran MSKE. Berdasarkan hasil analisis data tentang validasi, kepraktisan, dan efektifitas training kit kendali elektronik yang dikembangkan dapat disimpulkan bahwa Training kit kendali elektronik dikategorikan valid, dengan rata-rata persentase yang diperoleh relative besar, sehingga sudah memenuhi aspek komponen isi dan tujuan, aspek instruksional, dan aspek teknis media pembelajaran. Praktis digunakan setelah di uji coba produk dan pemakaian dengan persentase besar 
dapat kategori sangat praktis, dengan demikian dapat disimpulkan bahwa media training kit kendali elektronik praktis dan memenuhi syarat dalam aspek kepraktisan yaitu kemudahan dalam penggunaan, efisiensi waktu, mudah diinterprestasikan dan memiliki ekivalensi. Efektif digunakan setelah uji keterampilan siswa pada tahap uji coba produk dan uji coba pemakaian karena persentase ketuntasan lebih besar dibandingkan syarat dari ketuntasan klasikal. Pada uji coba produk diperoleh persentase ketuntasan belajar siswa sangat memuaskan.

Dari simpulan di atas, penulis memberikan saran kepada beberapa pihak, pertama bagi guru pengajar mata pelajaran mengoperasikan sistem kendali elektronik di SMK Negeri 2 Lubung Basung bahwa kendali elektronik merupakan teknologi yang dapat dikembangkan di berbagai disiplin ilmu pengetahuan, dalam hal ini pengajar hanya fokus pada mata pelajaran sebagai fungsi yang dapat diaplikasikan pada perangkat elektronik di dunia industri, disarankan bagi setiap pengajar dapat mengembangkan suatu produk training kit untuk membuat inovasi baru pada bidang lain, seperti bidang energi, pertanian, kesehatan dan perkebunan.

Saran kepada peneliti selanjutnya yang akan mengembangkan produk training kit sistem kendali elektronik dalam Pemilihan Komponen elektronika disarankan lebih mempertimbangkan aspek harga, tempat penyimpanan produk, serta bisa mengaitkan dengan kemajuan teknologi dan memberikan sebuah project-based learning kepada peserta didik setelah menggunakan training kit agar lebih memahami fungsi dari setiap komponen - komponen pada produk yang di kembangkan.

\section{DAFTAR PUSTAKA}

[1] Amin, A. K., Mayasari, N. (2015). Pengembangan Media Pembelajaran Berbentuk Aplikasi Android Berbasis Weblog Untuk Meningkatkan Hasil Belajar Mahasiswa Pendidikan Matematika Ikip Pgri Bojonegoro. Magistra, 94(27), 12-23.

[2] Alfasimi, D. R., Krismadinata, K., Sukardi, S., Syukhri, S. (2018). Pengembangan Training Kits Pengukuran Listrik Sebagai Media Pembelajaran pada Mata Pelajaran Memahami Pengukuran Komponen Elektronika di SMK Muhammadiyah 1 Padang. Jurnal Inovasi Vokasional dan Teknologi. 18(1). 91-99.

[3] Nurkholis. (2013). Pendidikan Dalam Upaya Memajukan Teknologi. Jurnal Kependidikan. 1(1). 24-44.

[4] Sarwo, E. , Suharno, Indah W. (2017). Pengembangan Standar Pelaksanaan Praktik Kerja Industri (Prakerin) Siswa Smk Program Keahlian Teknik Pemesinan Di Wilayah Surakarta. JIPTEK. 10(1). 22-30.

[5] E. S. Haq and H. Yuliandoko, "Trainer Mikrokontroler Sebagai Media Pembelajaran Untuk Meningkatkan Kompetensi Siswa Di SMK Negeri Banyuwangl," SEMNASTEKNOMEDIA ONLINE, vol. 2, no. 1, pp. 1-11, 2014.

[6] Arsyad, A. (2016). Media Pembelajaran. Jakarta: Rajawali Pers.

[7] M. A. Hamid et al., Media Pembelajaran. Medan: Yayasan Kita Menulis, 2020

[8] Krismadinata, K., Elfizon, E., Santika, T. (2019). Developing Interactive Learning Multimedia on Basic Electrical Measurement Course. 5th UPI International Conference on Technical and Vocational Education and Training, ICTVET 2018, Indonesion. 299, 305-308.

[9] Sukoco, Zainal, A., Sutiman, Muhkamad, W. (2014). Pengembangan Media Pembelajaran Interaktif Berbasis Komputer Untuk Peserta Didik Mata Pelajaran Teknik Kendaraan Ringan. Jurnal Pendidikan Teknologi dan Kejuruan. 22(2). 215-226.

[10] Suwarno, W. (2006). Dasar-Dasar Ilmu Pendidikan. Jogjakarta: AR-Ruzz Media Jogjakarta.

[11] Rahmayanti, (2015). Penggunaan Media It Dalam Pembelajaran. Jurnal IImiah CIRCUIT. 1(1). 85-97.

[12] Chandra, A., R. (2018). Pengembangan Trainer KIT Sensor Berbasis ATMEGA32 Sebagai Media Pembelajaran pada Mata Kuliah Sensor dan Tranduser. JUPITER (Jurnal Pendidikan Teknik Elektro). 3(2). 13-18.

[13] Mohammad Zulkarnain O., Amar Faiz Z.A., Syahrul Hisham M. (2019). E-Logic Trainer Kit: Development of an Electronic Educational Simulator and Quiz Kit for Logic Gate Combinational Circuit by Using Arduino as Application. International Journal Of Online and Biomedical Engineering. 15(14). 67-77.

[14] Amrullah, Aminuddin. (2018). Rancang Bangun Media Pembelajaran Praktik Alignment. Jurnal Sosial Humaniora Dan Pendidikan. 2(1). 59-63.

[15] Ahmad, L., S., Nurhening, Y. (2017). Pengembangan Media Pembelajaran Trainer Kit Sistem Pengendali Elektromagnetik. Jurnal Pendidikan Teknik Elektro. 7(4). 265-272.

[16] Isran R., K., K., S., Rohani, (2018). Manfaat Media Dalam Pembelajaran. AXIOM. 7(1). 91-96. 
[17] Iwan F., (2014). Pemanfaatan Media dalam Pembelajaran. Jurnal Lingkar Widyaiswara. 1(4). 104-117.

[18] Emzir. (2010). Metodologi Penelitain Pendidikan: Kuantitatif dan Kualitatif. Jakarta: Rajawali Press.

[19] Sugiyono. (2013). Metode Penelitian kuantitatif, kualitatif \& Pengembangan Research and Development. Bandung: Alfabeta.

[20] Riduwan. (2010). Belajar Mudah Penelitian Untuk Guru, Karyawan dan Peneliti Pemula. Bandung: Alfabeta. 